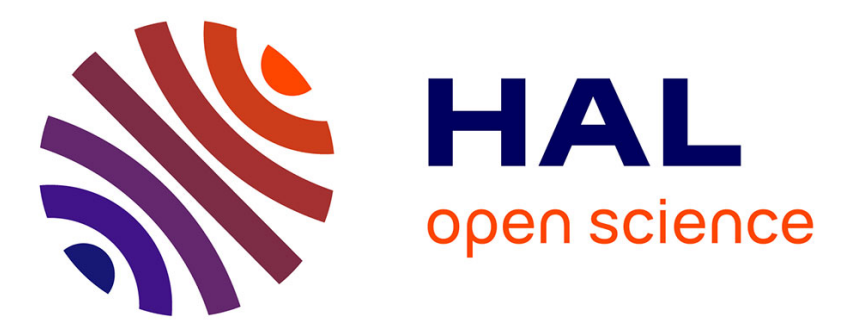

\title{
Medicine and management in European healthcare systems: how do they matter in the control of clinical practice?
}

Ellen Kuhlmann, Viola Burau, Christa Larsen, Roman Andrzej Lewandowski, Christos Lionis, José Repullo

\section{To cite this version:}

Ellen Kuhlmann, Viola Burau, Christa Larsen, Roman Andrzej Lewandowski, Christos Lionis, et al.. Medicine and management in European healthcare systems: how do they matter in the control of clinical practice?. International Journal of Clinical Practice, 2011, 65 (7), pp.722. 10.1111/j.17421241.2011.02665.x . hal-00635799

\section{HAL Id: hal-00635799 https://hal.science/hal-00635799}

Submitted on 26 Oct 2011

HAL is a multi-disciplinary open access archive for the deposit and dissemination of scientific research documents, whether they are published or not. The documents may come from teaching and research institutions in France or abroad, or from public or private research centers.
L'archive ouverte pluridisciplinaire HAL, est destinée au dépôt et à la diffusion de documents scientifiques de niveau recherche, publiés ou non, émanant des établissements d'enseignement et de recherche français ou étrangers, des laboratoires publics ou privés. 


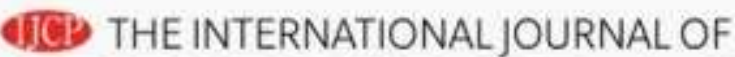 CLINICAL PRACTICE}

\section{Medicine and management in European healthcare systems: how do they matter in the control of clinical practice?}

\begin{tabular}{|c|c|}
\hline Journal: & International Journal of Clinical Practice \\
\hline Manuscript ID: & IJCP-02-11-0057 \\
\hline Wiley - Manuscript type: & Perspective \\
\hline $\begin{array}{r}\text { Date Submitted by the } \\
\text { Author: }\end{array}$ & 06-Feb-2011 \\
\hline Complete List of Authors: & $\begin{array}{l}\text { Kuhlmann, Ellen; University of Bath, Social and Policy Sciences } \\
\text { Burau, Viola; University of Aarhus, Department of Political Science } \\
\text { Larsen, Christa; Goethe University Frankfurt } \\
\text { Lewandowski, Roman; Kotarbinski Academy of Informatics and } \\
\text { Management in Olsztyn } \\
\text { Lionis, Christos; University of Crete, School of Medicine } \\
\text { Repullo, José; Carlos III University Madrid }\end{array}$ \\
\hline Specialty area: & \\
\hline
\end{tabular}

\section{SCHOLARONE" Manuscripts}




\section{Title page}

Medicine and management in European healthcare systems: how do they matter in the control of clinical practice?

Ellen Kuhlmann*, Viola Burau, Christa Larsen, Roman Lewandowski, Christos Lionis, and José Repullo

\section{Addresses}

* Corresponding author

Dr Ellen Kuhlmann

University of Bath, UK

Email: e.c.kuhlmann@bath.ac.uk

Dr Viola Burau

University of Aarhus, Denmark

Email: viola@au.dk

Dr Christa Larsen

Goethe University Frankfurt, Germany

Email: c.larsen@em.uni-frankfurt.de

Prof Dr Roman Lewandowski

Voivodeship Rehabilitation Hospital for Children in Ameryka, Poland

Email: rlewando@wp.pl

Prof Dr Christos Lionis

University of Crete, School of Medicine, Greece

Email: lionis@galinos.soc.med.uoc.gr

Dr José Repullo

Institute for Health Carlos III, Madrid, Spain

Email: irepullo@isciii.es 


\title{
Medicine and management in European healthcare systems: how do they matter in the control of clinical practice?
}

\author{
Ellen Kuhlmann, Viola Burau, Christa Larsen, Roman Lewandowski, Christos Lionis, \\ and José Repullo
}

During recent years, management has brought tighter controls into all areas of clinical practice, responding mainly to financial shortages coupled with increasing public demand for quality and safety of care. Management is not simply expanding and creating new roles for non-clinical managers, but doctors, too, are charged with managerial responsibilities. Consequently, the boundaries between medicine and management are no longer sustainable and this, in turn, may have complex implications for control and leadership in clinical practice.

The notion of control, as defined here, includes a wide range of bureaucratic measures and managerial tools, such as target setting; performance indicators; and interventions for which doctors have oversight, such as evidence-based clinical guidelines or continuing professional development. The pros and cons of managerialist regimes in clinical practice, as well as the challenges of managing doctors, are widely debated. A growing body of literature reveals the problematic outcomes of new managerial tools, which include standardisation, evidencebased medicine, and target setting, as well as financial incentives and new managerial roles (Galloway, 2009; Knorring et al, 2010; McDonald et al, 2008; Minhas, 2009; Timmermans and Amelung, 2009).

But what is next in exploring how the transformations in medicine and management matter in the control of clinical practice? If medicine and management are no longer sitting on 'different planets', it is time to move beyond the 'either-or' questions of professional or managerialist controls and, instead, explore the connections. There is an urgent need to develop and implement models that are able to effectively connect professional self-governing and management-based controls in clinical practice. The way forward is informed by rich casestudy material from Denmark, England, Germany, Greece, Poland, and Spain. Research was carried out by the authors and includes analyses of policy documents and primary and secondary sources.

\section{Where are we now?}

Across European healthcare systems the attempts towards tighter control of clinical practice seek to improve both cost-efficiency and quality of care. Thus, two key areas in need of control can be identified:

- Control of budgets: In many countries, this has taken the form of DRGs, and the focus is consequently on the organisation. In addition, pay-for-performance schemes and other financial incentives that are more directed at individual professionals are also relevant;

- Control of quality and safety of patients: Examples of this type of control are diverse and may even include organisational restructuring and the creation of new institutions. But evidence-based medicine and clinical guidelines are key strategies in 
all countries, primarily nurturing individual approaches and the self-governing professional controls of doctors.

These examples highlight the fact that medicine and management are 'twin forces', and as such indicative of new emergent controls. In both areas, the self-governing professional controls and more individualised strategies co-exist with tighter organisational controls. What matters is the relative balance between the two and the specific composition of the toolset of controls. Some illustrative examples reveal different patterns of control in European countries.

\section{Variations on the theme}

In Denmark, quality standards have evolved from the bottom up, beginning in hospitals. This has been further developed by a national programme and includes accreditation processes of self-evaluation by the organisation and external evaluation by a professional accreditation association. Consequently, managerial and professional controls are more integrated, but the balance is shifting from the individual professional towards organisation-based criteria of quality control.

- Control is linked to integrated approaches but focuses more on the organisation than on individual doctors.

The NHS in England counts as a prime example of the implementation of new managerial regimes. Within this context, target setting and standardisation are key to improving both the quality of care and budget control. Doctors have widely adopted these strategies without significant conflict, and individual professionals and organisations may collaborate towards transformations of the content of targets and standards.

- Control focuses more on the organisation together with strong centralised controls and some individual incentives.

Managerial controls in Germany focus mainly on doctors, and in turn, doctors use the new managerialism strategically in order to reinforce their self-governing capacities. Examples of this include the introduction of clinical guidelines and continuing professional development (CPD) as a mandatory requirement by law. In this situation, existing working groups established by doctors ('quality circles') were assigned to approve CPD, which subsequently expanded rapidly. This self-governing professional control co-exists with a number of new budget controls, such as DRGs, that are more focused on the organisation.

- Control focuses more on individual doctors, but budget controls shift the focus towards the organisation.

Efforts towards clinical management have been reinforced in Greece and in Poland, but a number of new mechanisms of control in which doctors still have oversight have been established. Doctors are, to a large extent, the key players who shape the outcomes of control in clinical practice. However, this pattern may co-exist with other forms. For example, health authorities in Greece have recently gained oversight of the improvement of both 
budget control and quality of drug prescriptions; by contrast, budget control in Poland is coupled with the commercialisation of hospitals and a DRG system, thus reinforcing market control.

- Control is more focused on individual doctors and self-governance than on organisational innovation, but it co-exists with both market control and more centralised state controls.

Restructuring of hospital management in Spain primarily includes financial management, such as the management contracts linked to a DRG system. This restructuring, however, is accompanied by organisational change in the top management and the medical hierarchy as well as new efforts to rebuild medical professionalism towards leadership. There are also innovations in management, such as the introduction of a pilot scheme with more integrated management or new forms of clinical leadership that improve doctors' budget responsibility.

- Managerial and professional controls are connected and re-connected in different ways, including more integrated management and other organisational innovations.

\section{What next in researching control?}

The case study material reveals that no uniform model of control emerges across European healthcare systems. At the same time, we can observe in all countries a co-existence of selfgoverning professional controls and managerial controls that may be targeted at individuals and organisations and may also be linked with markets and hierarchical state controls. What matters in the control of clinical practice in European healthcare systems is the specific composition of a set of controls and how they are connected and re-connected and may create new more 'hybrid' patterns of controls.

These emergent patterns of control may be linked to the institutional framings of medicine and management to some degree, as shown in our examples, but other conditions, including the subject area of control and the time-specific frame, are also relevant and might even override the institutions' importance. Consequently, researching control presents new challenges. First, the new connectedness of medicine and management calls for a more dynamic and reflective theoretical approach to control that moves beyond the assumption of contradicting logics; this also brings a transformative potential of professionalism and 'hybridization' of control into perspective (Kirkpatrick et al, 2009; Plochg et al, 2009). Second, comparative research draws heavily on typologies and indicators that were created at the level of health systems (Wendt et al, 2009). But the management of medical performance focuses on organisations and professional groups, and therefore calls for new approaches, including qualitative methods, meso-level comparison, and actor-centred dynamics.

We suggest exploring the emergent patterns of control more systematically by focusing on the organisational settings in different European healthcare states and the actors involved in the transformations. Organisations are the 'switchboards' of clinical practice, where 'medicine meets management' and control is made and re-made. Using cross-country comparison adds further value by filtering out how organisational settings matter in relation to the wider architecture of healthcare states. Finally, this will help to outline future avenues for 'medicine 


\section{Acknowledgements}

This article draws on research carried out by Working Group 2 (Control) of the 7th EU Framework Programme COST Action IS0903 "Enhancing the Role of Medicine in the Management of European Health Systems: Implications for Control, Innovation and User Voice", chaired by Professor lan Kirkpatrick. For further information please visit: http://www.cihm.leeds.ac.uk/new/cost/

The authors declare that they have no conflict of interest.

\section{Addresses}

Dr Ellen Kuhlmann

University of Bath, UK

Email: e.c.kuhlmann@bath.ac.uk

Dr Viola Burau

University of Aarhus, Denmark 
Email:viola@au.dk

Dr Christa Larsen

Goethe University Frankfurt, Germany

Email: c.larsen@em.uni-frankfurt.de

Prof Dr Roman Lewandowski

Voivodeship Rehabilitation Hospital for Children in Ameryka, Poland

Email: rlewando@wp.pl

Prof Dr Christos Lionis

University of Crete, School of Medicine, Greece

Email: lionis@galinos.soc.med.uoc.gr

Dr José Repullo

Institute for Health Carlos III, Madrid, Spain

Email: jrepullo@isciii.es 